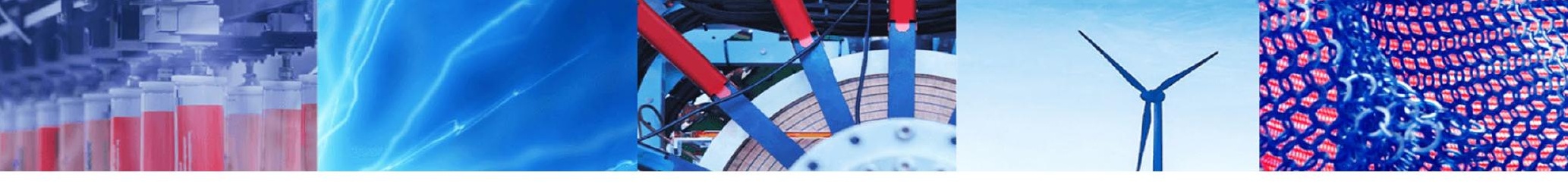

Research Article

\title{
3D modeling of faults and stability analysis of Dardvey mine in Sangan iron skarn complex, Iran
}

\author{
Mehdi Brookhian ${ }^{1} \cdot$ Hamid Raza Golkar Hamzee Yazd ${ }^{1}$ (1) $\cdot$ Mojtaba Tavousi $^{1}$
}

Received: 17 April 2020 / Accepted: 13 November 2020 / Published online: 28 November 2020

(c) Springer Nature Switzerland AG 2020

\begin{abstract}
The system of water flow into the Sangan mineral pit, located in NE Iran, has a direct relationship with the deformations, fractures, and faults. This study aims to investigates, identifies, and analyze the tectonic structures in the Sangan Dardvey deposit, and to determine the regional structural model, deposit structural patterns, and finally provide the deposit's 3D formation model for water entry. The Sangan mining region is located at the end of one of the large-scale branching terminals of the Dorouneh fault, this block is considered a part of a tectonic escape in terms of regional tectonics, and most of the groundwater in the region can be attributed to its activity. The fault density map has been prepared by investigating the faults existing in the deposit area and analyzing the spatial density of faults. The map shows that three faults zones in the Dardvey deposit area are in the E-W, NE-SW, and NW-SE strikes with a dip angle $\left(70^{\circ}-80^{\circ}\right)$. These fault areas can create paths for the entrance of groundwater into the mineral deposit. Moreover, the structural studies have shown that in the Sangan Dardvey deposits, the fractures play a crucial role in the fault zones, to which the existing anomalies are directly related. The estimation of water entry in the Dardvey deposits has been mainly controlled by tectonic structures.
\end{abstract}

Keywords Geological structure $\cdot$ Modeling $\cdot$ Fault $\cdot$ Dardvey deposit $\cdot$ Sangan $\cdot$ Iran

\section{Introduction}

Like many large open-pit deposits of the world, the Sangan mineral deposit deals with the issues concerning rock engineering, the stability of walls [27], and exploration during mining $[30,36]$. Slope stability issues, like geological and tectonic features [8, 9], are intrinsically complex and variable [25]. Evaluation of structural characteristics by mine designers for proper planning of mining requires accurate information on the stability state of the walls and the ore grade. Furthermore, the presence of water in mining sites can cause problems in mining operations and mine stability $[4,14,18]$. Water can enter a mine through leakage [7] of surface water resources [26], as well as penetration of rainwater or groundwater. The volume of water penetration through such means depends on the type and size of fractures in the rock mass [19], hydraulic head, and depth of the aquifer [21]. Therefore, precise information about rock mass properties [10], tectonic properties of mine as the necessary data (Feng et al., [10,11], and volume of water penetration are required to achieve an ideal and proper model. In open-pit mines, it is crucial to determine the structural condition and geological engineering properties of host rock masses, partition them along the slopes and stabilize them (in a tectonized and stable form) [35].

Electronic supplementary material The online version of this article (https://doi.org/10.1007/s42452-020-03893-7) contains supplementary material, which is available to authorized users.

Hamid Raza Golkar Hamzee Yazd, Glokar.hr@ferdowsiau.ac.ir; Mehdi Brookhian, Brookhian.m@gmail.com; Mojtaba Tavousi, m_ tavoosi54@yahoo.com | 'Department of Water Engineering, Ferdows Branch, Islamic Azad University, Ferdows, Iran. 
Brems et al. [5] evaluated the metallogeny of southern Nkana copper-cobalt deposits in Zambia. They found that the geological structures of the studied deposits were related to the grade distribution. Torremans et al. [33] investigated the effect of tectonic properties and structural control on the ore grade distribution in the Konkola copper-cobalt deposit located in Zambia. The evaluations and distribution maps of copper and cobalt indicated that there was a close relationship between the structural properties and ore grade distribution in this mine. Gongwen et al. [13] carried out a quantitative evaluation of mineral resources by integrating the geostatistical and fractal methods in the copper deposit of Tongshan in China. The results demonstrated that the Hurst exponent function was useful in identifying the continuity of vertical mineralization (within the range of $0-1200 \mathrm{~m}$ ). The 3D geological and trend model could be integrated to determine the subsurface targets in the Tongshan deposit. Huang et al. [17] conducted 3D modeling of the Cangshang gold mine using Surpac software. The model helped them in the calculations of the deposit and designing the mine in the production phase. They also used a manual method and compared their results with those of the software, which showed that the results were of high accuracy. Vollgger et al. [34] introduced a new approach to analyze and assess the structural framework of deposits by integrating the 3D modeling of environments with sufficient information with field observations. In their study, the Navachab gold deposit in the Damara orogenic belt, located in Namibia, was investigated. High-grade mineralization trends were identified, which were directly related to the structures observed in the field. Liu et al. [20] conducted the 3D modeling of the porphyry-related Dawangding gold deposit in south China. They employed knowledge-driven methods to build 3D geometric models of the deposit and intrusions using FLAC3D software. In Iran, Rezaei et al. [29] built a 3D fracture model through ground-penetrating radar and resostivity methods and assessed the unstable tectonic areas in the C-North deposit using the variations of geophysical parameters of geological structures. In other studies, the Dardevey iron ore deposit in Sangan Iron Skarn Complex, NE Iran, was investigated. Shahbeik et al. [32] investigated the comparison between ordinary kriging (OK) and inverse distance weighted (IDW) based on the estimation error. Their results indicate that the error estimation of OK method is less than IDW method and that the results of OK method are reliable. Afzal et al., [1] identified the effect of ordinary and straightforward multi-Gaussian kriging (oMK, sMK) estimation methods for the delineation of iron mineralized zones based on subsurface data using Concentration-Volume $(C-V)$ fractal modeling. Spatial data analyses (variograms and anisotropic ellipsoid) were initially calculated for the Fe distribution. The $C-V$ log-log plots based on the estimation methods represent the various mineralized zones via threshold values. The comparison and interpretation of the mineralized zones based on the $C-V$ fractal modeling show that the methods are similar, but the enriched and highly zones resulted by the oMK have variances lower than the sMK method. Furthermore, the weakly and moderately mineralized zones have lower variances based on the sMK method.

The objectives of their study were to evaluate and identify the tectonic structures in the mine and analyze those using proper methods to achieve a 3D tectonic model for a safe and economical design of slope. For this purpose, in the first step of this study, by using satellite images of LandSat8 and ASTER, the required filters were applied, and lineaments in the Sangan Dardvey mine were extracted. The structural surveying stations were defined based on the results of remote sensing, geological maps, and field observations. The Dardvey deposit of the central anomaly was selected for this study. In the second step, the structural surveys (faults and fractures) in different walls were conducted based on the diffenence in the lithology. Then, the statistical analysis of each wall was performed separately using Dips.5.1 software, which included the pole plot, contour plot, rose diagram, and the major plane plots of the fractures and faults. In the third step, the 3D modeling of fractures and faults was conducted for the Dardvey deposits using Surpac 6.6.2 software.

\section{Description of the study area}

\subsection{Geographical situation}

Of the main deposits related to the Tertiary volcanic-plutonic magmatism in NE Iran is the iron skarn complex of Sangan. The study area is located at the southeast of the Khorasan-e-Razavi Province, which is approximately $280 \mathrm{~km}$ away from the city of Mashhad. This area has a regional $\mathrm{E}-\mathrm{W}$ trend (it lies between longitudes $60^{\circ} 10^{\prime}$ $00^{\prime \prime}-60^{\circ} 50^{\prime} 00^{\prime \prime} \mathrm{E}$ and the latitudes $34^{\circ} 20^{\prime} 00^{\prime \prime}-34^{\circ} 40^{\prime}$ $00^{\prime \prime} \mathrm{N}$ ) and is situated at the end part of the Khaf-Kashmar-Bardskan Tertiary magmatic belt of the Central Iran block and close to the eastern segment of the large-scale Doruneh fault (Fig. 1a). Being located at the NE of the Lut block, the Sangan Magmatic Complex (SMC) constitutes thick piles of volcanic rocks with younger granitoid intrusions [31]. SMC contains several ore bodies with a prevailing east-west direction. This mining region is divided into different parts based on the characteristics of these ore deposits: the western [including $A, A^{\prime}, B, C S$ (C-South), CN (C-North), and central (including Baghak (BA) and Dardvey (D)] (Fig. 1a) and eastern (including Senjedak 1, 2, 3, 

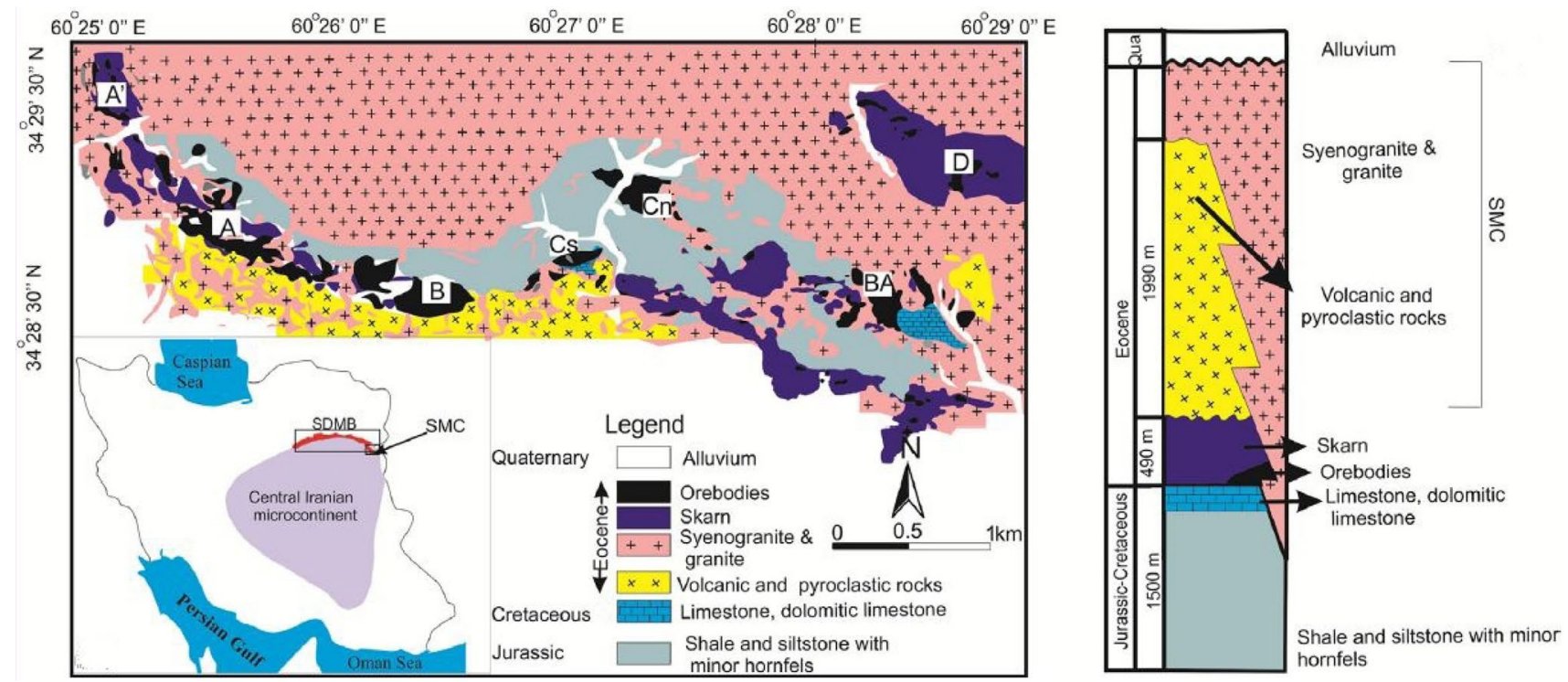

Fig. 1 a The Iran map together with the geological map of the Sangan region. The locations of the Sangan deposits, as well as the Eocene volcanic and plutonic rocks, are shown (they are derived from the geological maps of Taybad with the scale of 1:250,000)

Madanjoo, Som-Ahanai, and Ferezneh) anomalies. The Sangan iron skarn deposits are scattered over an area along the contact zones of the Jurassic clastic/Cretaceous carbonates and Eocene igneous rocks (Fig. 1b) [12, 22].

\subsection{Geological setting}

There are a lot of varieties of geological formations in the area under study. Because there are hydrogeological and geological investigations in the study area, it is possible to classify the main geological formations which contain groundwater as 1. Jurassic and Cretaceous limestone; 2. Paleocene and Eocene intrusive and volcanic rocks; 3. Neocene sedimentary rocks. Tuff and rhyolite, which were weathered and crashed, are mainly main volcanic rocks. The Sangan ore deposit, which is detected as a skarn irontype, is elongated from east to west of Taleb mountain. There are various rock types for detecting in the Sangan mine, including Sarnosar granite, siltstone, sandstone and quartzite complex, north skarn unit, shale and siltstone, south skarn unit and volcanic complex, carbonate rocks and marn and quaternary sediments. It is possible to classify the iron ores in Sangan into the high-grade massive iron zone, low-grade dispersive iron zone, oxidized zone, and sulfide zone. Western, central and eastern zones are considered as the three minable zones of the Sangan iron deposit. Approximately the western section is prepared enough to extract. This area covering an area about $6 \mathrm{~km}^{2}$ consists of five anomalies, $A, A^{\prime}, B$, south $C\left(C_{s}\right)$, and north
[3]. The simplified geological map of the western [including $A, A^{\prime}, B$, C-South (Cs), and C-North (Cn)] and also central (including BA and D) anomalies has also been added to the map; $\mathbf{b}$ the stratigraphic columns of the Sangan region [23]

$C\left(C_{n}\right)$. The current study was carried out on one mass of Dardvay in the central zone (Fig. 2).

\section{Discussion}

\subsection{Enhancement of geological structures using remote sensing}

A high-pass directed kernel filter was used on the ASTER image bands to extract the lineaments along with visual interpretation. These structures could be observed using this filter. Directed (edge detection) filters are used to detect features, such as roads, streams, and faults for a particular purpose. The kernel directed filter was used. After applying the Laplacian filter in different directions, the area's structures, including lineaments and faults, were determined. The directed kernels were used to the PC1 image in four directions to extract the structural information. After the extraction of structures with the filtering technique, the obtained result was combined with that obtained from the visual interpretation of ASTER images to prepare the final map of facilities. The filters were used in the NE-SW, E-W, N-S, and NW-SE directions to increase the contrast frequency in the images (Fig. S1).

After the extraction of structures with the filtering technique, the obtained result was combined with that obtained from the visual interpretation of LandSat images to prepare the final map of facilities. Figure 3 shows the application of the Laplacian filter (Fig. 3a) and extraction 


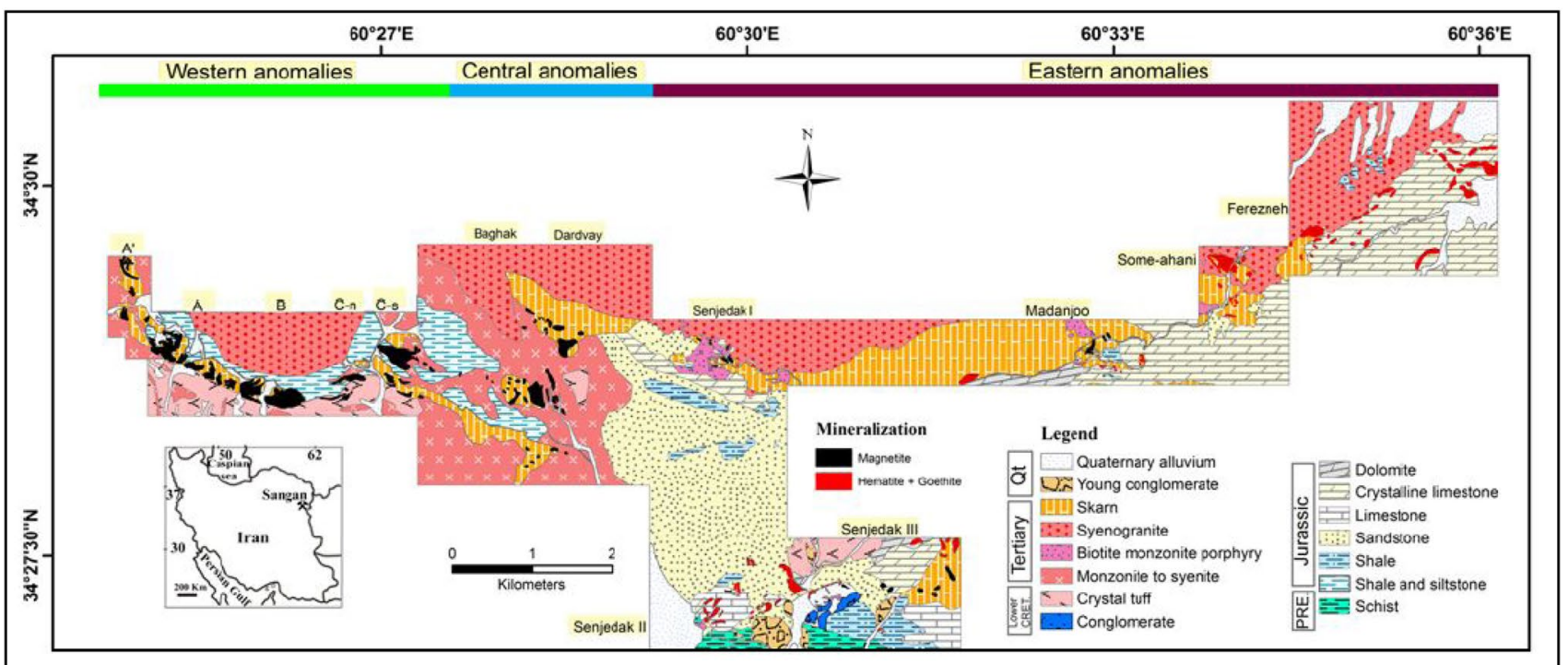

Fig. 2 Geological and structural map of Sangan iron ore mine

of the lineaments (Fig. 3b) on the LandSat8 satellite image in the study area.

\subsection{Evaluation of the structural pattern}

The most evident structure of the Sangan area is the Dardvey fault, which can be observed as broad lineaments in the satellite images. This fault, with an approximate $\mathrm{N} 30^{\circ} \mathrm{W}$ trend, continues as a long line outside the mine area, too. As it is evident in the filtered image (for extraction of the lineaments) (Fig. S2), the Dardvey fault has emerged evidently by displacing the two anomalies of Dardvey and Baghak. Given the location of Dardvey mass relative to Baghak, a left-slip separation is interpreted for the fault.

The area's faults are affected by a left-lateral shear zone. The structural pattern of the Dardvey deposit is shown as Fig. S3, based on a model suggested by Davis et al. [6]. The Dardvey left-slip fault can be considered the major surface, while the left-lateral strike-slip faults in the N, NW-S, SE directions are considered the Riedels (R) of this surface, and the right-lateral strike-slip ones in an E-S strike are regarded as Antiriedels ( $\left.R^{\prime}\right)$ of the surface. This model was built based on the directions of the stress field around the Dardvey fault with the maximum and minimum stress directions of NW-SE and NE-SW, respectively. Hybrid fractures were formed by the combination of compressional and extensional stresses at acute angles with the principal compressional stress.

Seven major faults were determined on the walls of the deposit. Table 1 presents the properties of the faults of the Dardvey deposit, and Fig. S4 shows the locations of structural surveying stations on the geological map. In this deposit, the faults F4 and F6, are vertical (slope of fault plane more than $80^{\circ}$ ), and the other faults are high-angle (slope of fault plane between $30^{\circ}$ and $80^{\circ}$ ).

\subsubsection{Faults F1 and F2}

The outcrops of these faults are revealed on the southern wall of the Dardvey deposit by different trends in the section containing magnetite mass with the angles of $43^{\circ}$ toward the southwest and $70^{\circ}$ toward the south, respectively. It seems both faults continue in the magnetite mass. The two faults intersect, which should be considered in the slope stability. The performance of these faults has caused numerous fractures in different directions in this part of the wall, which has resulted in the crushing of this zone (Fig. 4).

\subsubsection{Fault F3}

The outcrop of this fault is typically observed on the eastern wall of the Dardvey deposit with an NW-SE trend. The fault is visible between the magnetite mass and the granites around the mine with a direction of $40^{\circ}$ toward the northeast. Most of the changes in the southern and eastern walls of the deposit are caused by the activity of this fault, which has led to severe alterations in the rocks existing in this part and the crushing of the granites (Fig. 4).

\subsubsection{Fault F4}

The outcrop of this fault is observed on the northern wall of the Dardvey deposit with an approximate E-W trend. 
Fig. 3 a Application of the Laplacian filter to extract the lineaments and $\mathbf{b}$ extraction of the lineaments in the Sangan area (a)

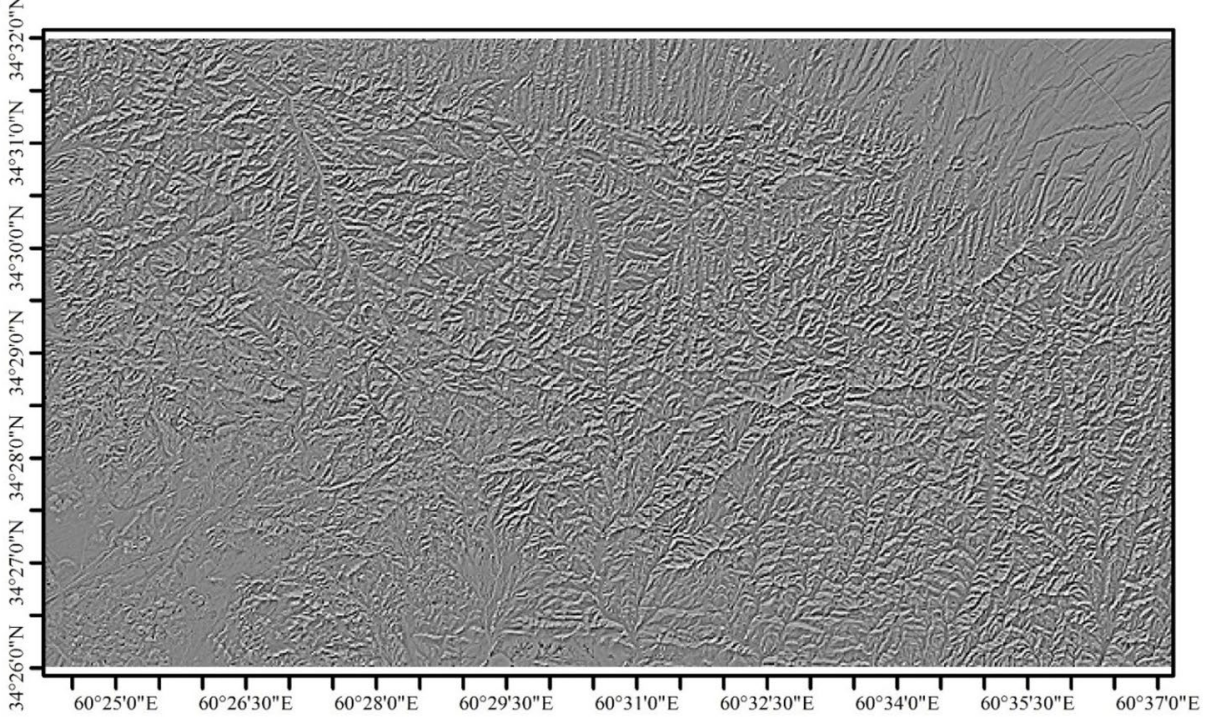

(b)

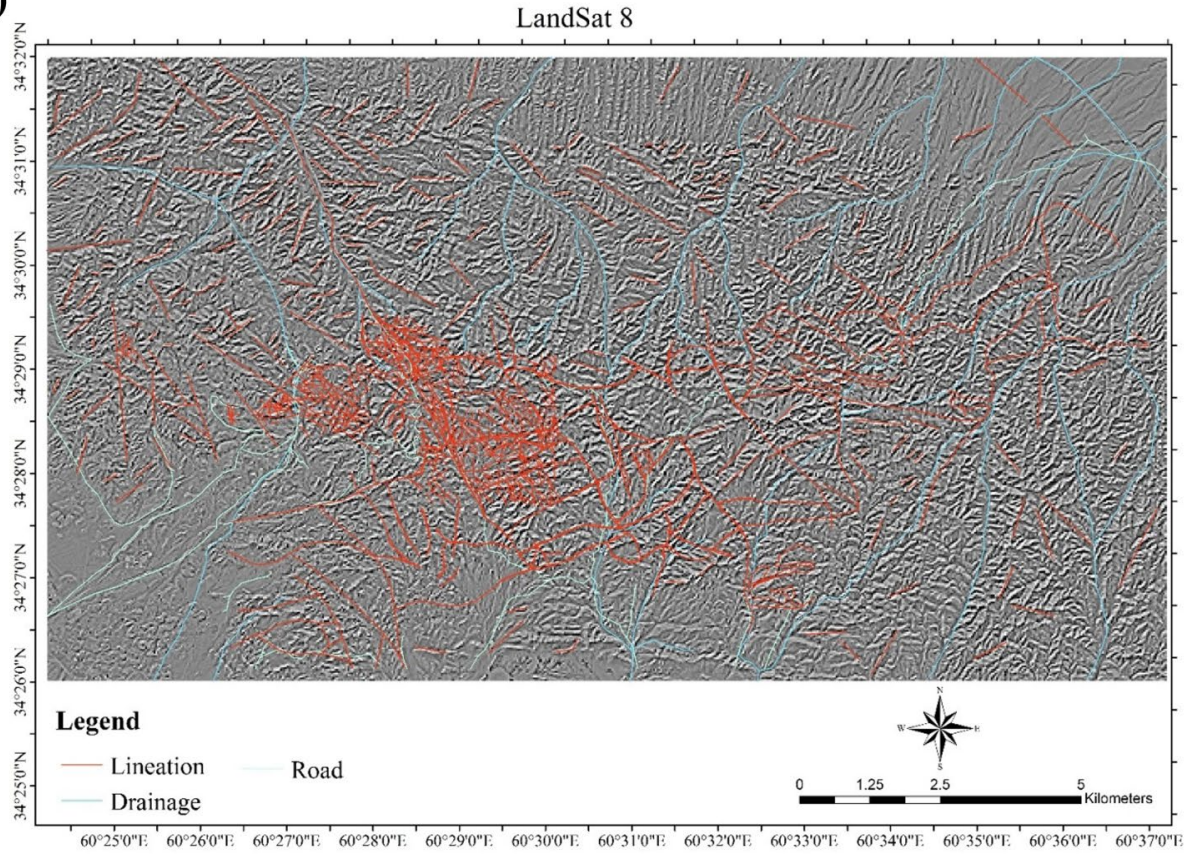

Table 1 Orientations of the faults of the Dardvey deposit area
The fault slope is $88^{\circ}$ toward the northeast. In other words, this fault is vertical. The penetration of hydrothermal solutions has caused severe alterations in the rocks of this part, including hematitation and limonitation. In this part of the deposit, the zone has been crushed, and the performance of the fault has caused several fractures in different directions, which should be taken into account in the slope stability (Fig. 4).

\subsubsection{Fault F5}

The outcrop of this fault has emerged on the northern wall of the Dardvey deposit with a NE-SW trend of $42^{\circ}$ toward 
Fig. 4 A view of the location of $\mathrm{F} 1$ and $\mathrm{F} 2$ faults on the southern wall (southward view), F3 fault on the eastern wall (eastward view), F4 fault on the northern wall (westward view), F5 fault on the northern wall (northwestward view), F6 fault on the northern wall (northward view), and F7 fault on the northern wall (northeastward view) in the Sangan Dardvey deposit
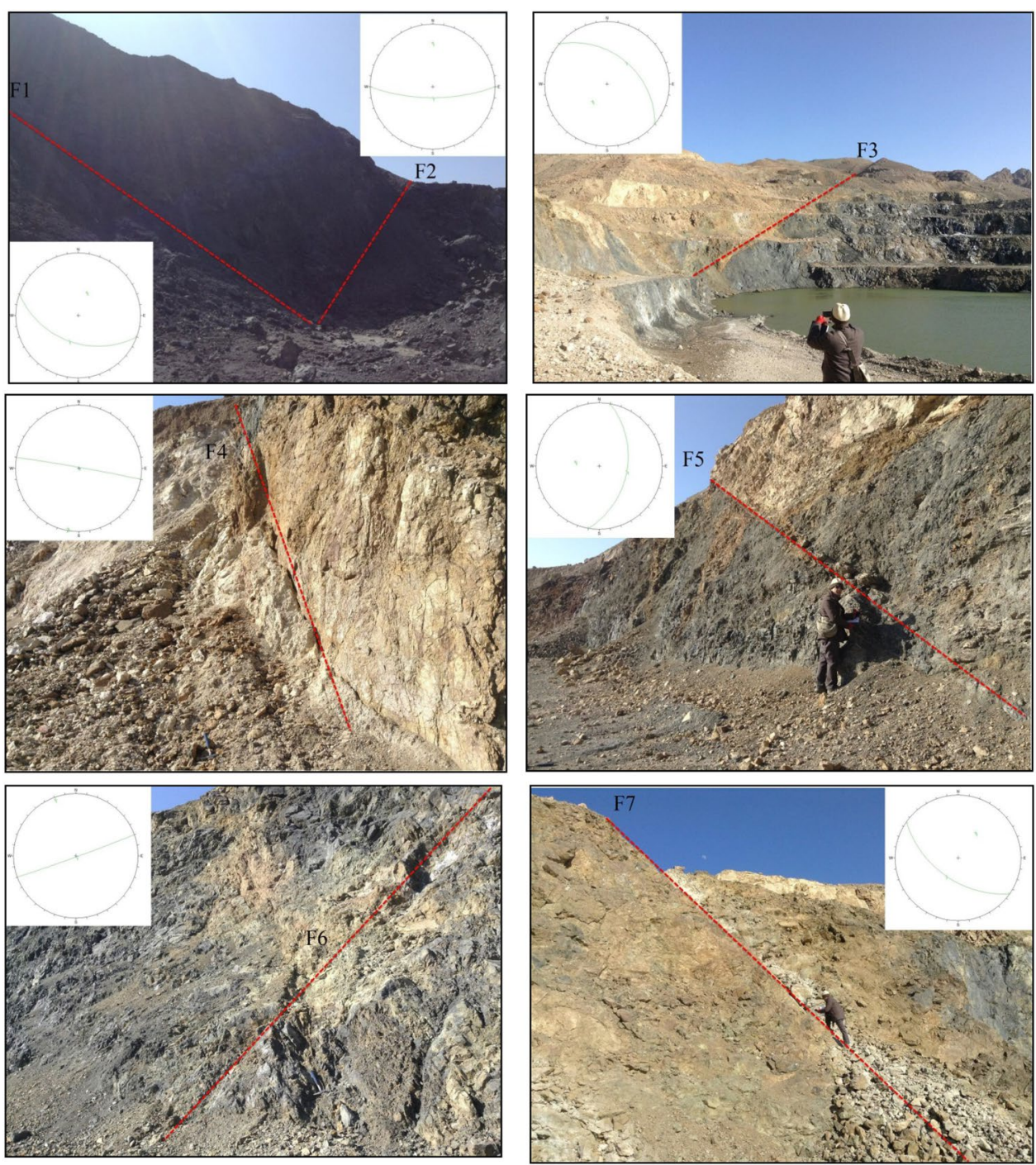

the southeast. This fault is also typically evident in the northern wall of the deposit. It seems this fault has caused many changes in the northern wall of the deposit, leading to a high level of crushing in this part of the deposit (Fig. 4).

\subsubsection{Fault F6}

The outcrop of this fault is observed in the northern wall of the Dardvey deposit with an approximate $\mathrm{E}-\mathrm{W}$ trend. The fault slope is $88^{\circ}$ toward the southeast. This fault is located at a distance of $30 \mathrm{~m}$ from the F5 fault. It seems severe crushing has occurred in this part of the deposit (Fig. 4).

\subsubsection{Fault F7}

The outcrop of this fault is visible on the northern wall of the Dardvey deposit with an approximate NW-SE trend, leading to the $\mathrm{F} 3$ fault. The fault has a slope of $52^{\circ}$ toward the southwest. This fault is located at a distance of $15 \mathrm{~m}$ from the F6 fault. The fault passes through the granite unit around the deposit and seemingly continues to the center of the deposit (Fig. 4).

\subsection{Statistical analysis of the faults}

The statistical distribution of the faults existing in the Dardvey deposit is shown in Fig. 5. The main structure of the region is controlled by the folds and fractures formed due to the changes caused by penetration of large granitoid masses of Sarnowsar and Bermani in the north and south of the area, respectively. The pressures caused by their penetration have resulted in the creation of critical tectonic structures in the area. The statistical evaluations showed that the Dardvey fault systems are NW-SE and W-E. It should be noted that some auxiliary faults have a $\mathrm{NE}-\mathrm{SW}$ trend.

\section{SN Applied Sciences}


Fig. 5 The statistical analysis of the faults in the Sangan Dardvey deposit, a pole plot, b contour plot, $\mathbf{c}$ rose diagram, and $\mathbf{d}$ plane plot of the faults

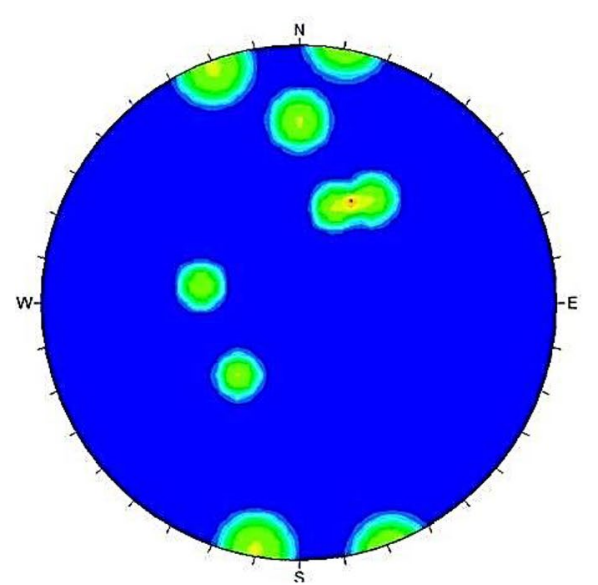

(b)

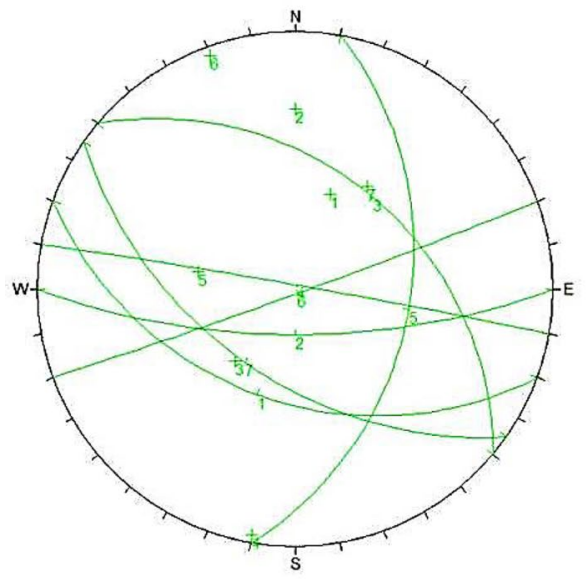

(d)

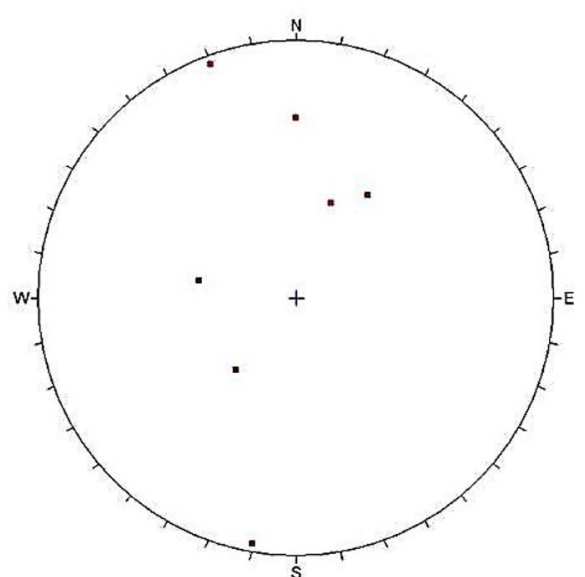

(a)

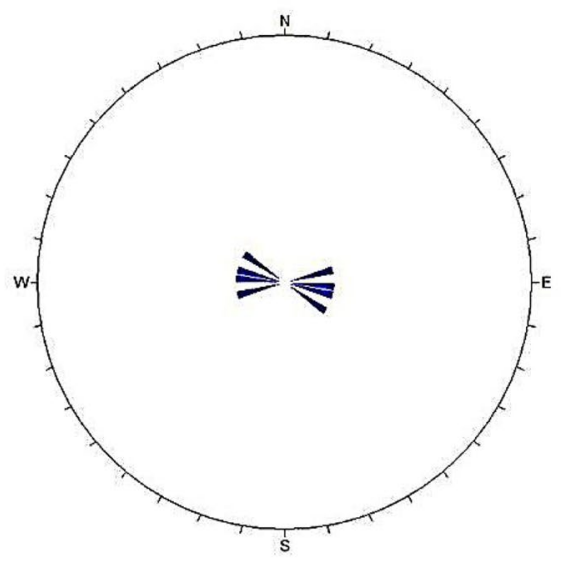

(c)
The Dardvey fault with an NW-SE strike is one of the most important structural features in the Dardvey mining area. This fault plays a significant role in the distribution of mineral deposits in the Sangan area, so that most faults of the area are expected to be affected by the movement of this fault. Most faults of the area are strike-slip. The leftlateral strike-slip faults, with N, NW-S, SE strikes, can be introduced as Riedel fractures of this fault. On the other hand, right-lateral strike-slip faults, mostly having E-W strikes, can be regarded as Antireidels of the fault. The normal faults have mainly an NW-SE strike and are distributed in the mining area.

Based on the structural analysis and surveys conducted in the Dardvey deposit, the fault systems in this mineral deposit are divided into three sets (according to Fig. 5):

1. Fault system with a W-E strike.

These faults of the deposit are older than the others. The faults in the south of the area have moved the igneous rocks closer to the carbonate rocks. Furthermore, the outcrop of these rocks conforms to this fault system.

2. Fault system with a NE-SW strike.

These faults are younger than those of the first set. In most areas, some rightward displacements can be observed in the fractures of the region.

3. Fault system with an NW-SE strike.

These faults have a trend toward the east of the area, which has caused the displacements based on the trend of the faults in the south. Generally, the mineral deposit has moved with the structure of the area. It should be noted that faults with an N-S trend are observed in the Dardvey deposit. As the movement direction of the Doruneh fault has changed from right-slip to left-slip, the order of significant stress has become reversed, leading to a destructive phase in the region. The younger faults have displaced and 
cut the mineralization direction [24]. The properties of the structural surveying stations for the Dardvey faults present in Table 2 .

\subsection{D modeling of the faults using geostatistical methods}

The lineaments and faults of the Saveh region in the middle part of the Urumieh-Dokhtar Magmatic Belt (UDMB), Central Iran, were mapped using precise local data, including remote sensing (Landsat ETM+), digital elevation models (DEM), airborne geomagnetic images, geological maps, and field observations. The results of the C-A fractal modeling and Fry analysis indicate that the vein-style $\mathrm{Cu}$ mineralization is associated with major NW-SE-trending faults, especially the Khalkhab and Koshk-e-Nosrat faults. Manto-style Cu mineralization in the Saveh region is associated with minor NE-SW-trending faults [2].

The stability and reliability analyses of the slope of the walls in surface mines, especially the slope of the jointed rocks, are one of the most critical issues concerning the design of surface mines, which can be achieved with geotechnical modeling. In the structural investigations of the Dardvey deposit, we were calculated the fault density using the three parameters of fault length, intersection, and thickness. The size of the cells was considered $50 \mathrm{~m} \times 50 \mathrm{~m}$ in calculating the fault density. The fault density map was produced using two geostatistical interpolation methods, including inverse distance weight [28] and local polynomial [15].

The fault map was prepared using the fault density (FD) equation [16]:

$\mathrm{FD}=(a / A)+(b / B)+(c / C)$

where $a$ is the number of linear structures in the selected cell size, $A$ represents the average number of all lineaments in the map, $b$ is the length of the linear structures in the selected cell size, $B$ is the average length of all the faults in the map, $c$ is the number of the intersections of the faults in the selected cell size, and $C$ is the average number of complete intersections in the map. The region was divided into separate cells with appropriate dimensions $(50 \mathrm{~m}$ in this work) to create the map. The final FD map of the study area was produced after computing the numerical quantities of the proposed cells (Fig. 6). The derived relative ages of various fault sets are in the following.

The fault density maps indicate three main faults with NW-SE, W-E, and NE-SW trends in the Sangan Dardvey deposit. Moreover, the results of structural geological evaluations agree with the fault density map.

Based on the geostatistical analyses carried out on the faults of the Sangan Dardvey deposit, a 25-m buffer was chosen in this section (Fig. S5a). Figure S5b shows the fault density map, obtained from inverse distance weight and the 25-m buffer of the fault, combined with the structural geological results in the Sangan Dardvey deposit. The products of the integration of structural geological evaluations completely conform to the buffer map, which indicates the presence of extensive and useful fault zones in the Dardvey deposit.

According to previous observations, faults with an $\mathrm{N}-\mathrm{S}$ trend exist in the Dardvey deposit. As the movement direction of the Doruneh fault has changed from rightslip to left-slip, the order of significant stress has become reversed, leading to a destructive phase in the region. The younger faults have displaced and cut the mineralization direction.

Furthermore, the faults play an influential role in placing the stratigraphic units beside each other in the Dardvey deposit so that the lower Cretaceous lime is beside Eocene volcano sediments, and the Precambrian contact schists are located in the form of fault beside the lime. In addition to the layering of the levels, the symptoms of faulting, fracture, brecciation, slickenside, as well as variations of the dip and strike within small distances and the uplift and depression structures, all indicate the severe performance of the faults in the area, which have a significant role in the geometry and distribution of the mineral masses. The major faults of the Dardvey deposit area are shown in this section (Fig. S6).
Table 2 The properties of the structural surveying stations for the faults on the walls of the Sangan Dardvey deposit

\begin{tabular}{llllllll}
\hline Station & Wall & $X($ UTM $)$ & $Y($ UTM $)$ & Lithology & Dip direction & $\begin{array}{l}\text { Strike } \\
\text { (azimuth) }\end{array}$ & Dip angle $\left(^{\circ}\right)$ \\
\hline 1 & Southern & 267,660 & $3,819,120$ & Magnetite & N200 & 290 & 43 \\
2 & Southern & 267,660 & $3,819,130$ & Magnetite & N180 & 90 & 70 \\
3 & Eastern & 267,941 & $3,819,166$ & Skarn & N40 & 310 & 40 \\
4 & Northern & 267,618 & $3,819,335$ & Magnetite & N10 & 280 & 88 \\
5 & Northern & 267,697 & $3,819,314$ & Skarn & N100 & 10 & 42 \\
6 & Northern & 267,729 & $3,819,299$ & Skarn & N160 & 70 & 88 \\
7 & Northern & 267,739 & $3,819,291$ & Skarn & N215 & 305 & 52 \\
\hline
\end{tabular}




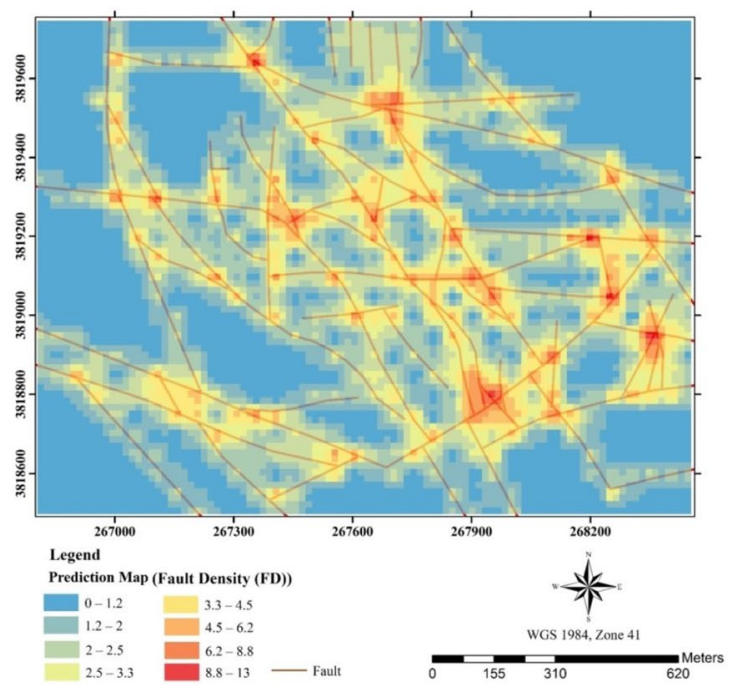

(a)

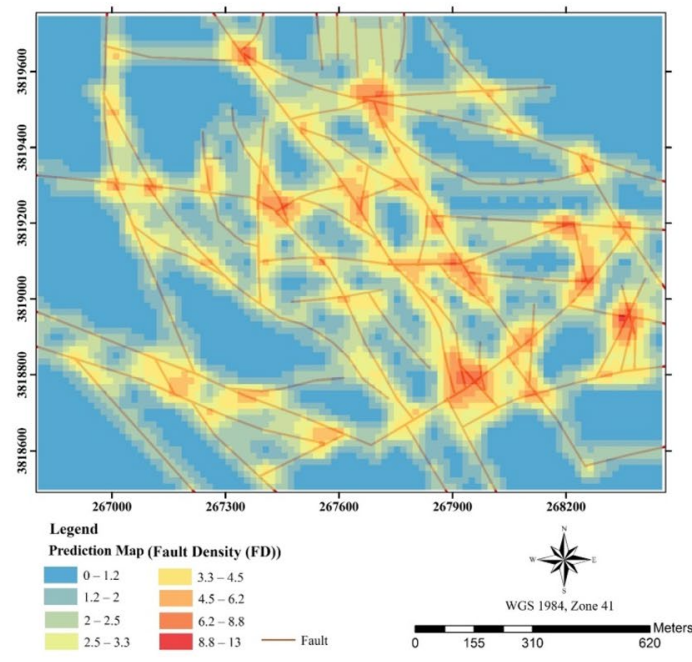

(b)

Fig. 6 The created fault density (FD) map by the a inverse distance weight (IDW) and b local polynomial (LP) methods for the Sangan area

Most of the faults with a NE-SW trend have a standard mechanism, while most of the faults with an NW-SE direction have a left-lateral strike-slip tool. There are also significant faults with an E-W trend, which are longer than the mentioned faults and play an essential role in the location of the mineral mass. In general, most faults of the area are faulted joints; thus, the compressional-shear stress system has had a significant role in the formation of the area's faults.

The variations of stress patterns in the Dardvey fault area demonstrate the crucial importance of this fault in the structures and fractures of the area. The left-lateral strike-slip movements of the Dardvey fault have formed new designs in the study area, affecting the older fractures and resulting in renewed displacements and new slips on the fracture surfaces. Therefore, given the variations of the stress field around the Dardvey fault, the stresses that have formed the left-lateral strike-slip faults have a younger age in comparison with the N-S extensional strains.

A sample of the geological section is shown in Fig. S7, along with the location of the faults and mineral masses in the Sangan Dardvey deposit.

Moreover, the 3D modeling of the faults in the Sangan Dardvey deposit based on the representative planes is shown in Fig. 7. The obtained structural map indicates a complex faulting mechanism in the study area.
Fig. 7 The 3D modeling of the faults based on the representative planes in the Sangan Dardvey deposit (northward view)

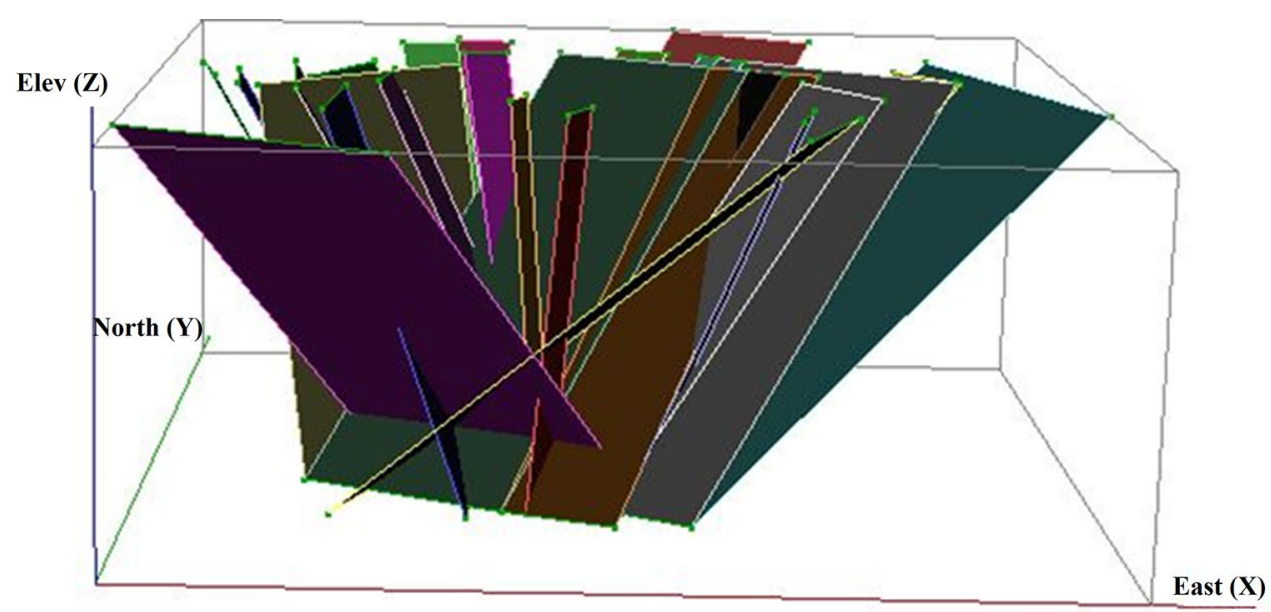

SN Applied Sciences A SPRINGER NATURE journa 


\section{Conclusions}

The wall height, geological conditions (especially structures), rock strength, and state of groundwater in mines are some of the factors affecting the stability of the mine slope and walls. A practical solution can be provided for this issue considering the geological data and geomechanical information, observing the conditions of groundwater, and making an accurate engineering judgment. Thus, the tectonic investigation of mines to determine the tectonic structure of the area and identify the faults and fractures can be of great importance in the stability of the walls, geotechnical studies, and exploration and extraction of minerals.

Based on the structural study in the Dardvey deposit, the fault systems in this mineral deposit are divided into three sets:

1. Fault system with a W-E strike. These faults of the deposit are older than the others. The faults in the south of the area have moved the igneous rocks closer to the carbonate rocks. Furthermore, the outcrop of these rocks conforms to this fault system.

2. Fault system with a NE-SW strike. These faults are younger than those of the first set. In most areas, some rightward displacements can be observed in the fractures of the region (normal faults).

3. Fault system with an NW-SE strike. These faults have a trend toward the east of the area, which has caused the displacements based on the trend of the faults in the south and west of the area.

The mineral deposit has generally moved with the structure of the area. It should be noted that faults with an N-S trend are observed in the Dardvey deposit. As the movement direction of the Doruneh fault has changed from right-slip to left-slip, the direction of significant stress has become reversed, leading to the formation of a destructive phase in the region. The younger faults have displaced and cut the mineralization direction. Furthermore, the faults play an influential role in placing the stratigraphic units beside each other in the Dardvey deposit so that the lower Cretaceous lime is beside Eocene volcano sediments, and the Precambrian contact schists are located in the form of fault beside the lime. In addition to the layering of the levels, the symptoms of faulting, fracture, brecciation, slickenside, as well as variations of the dip and strike within small distances and the uplift and depression structures, all indicate the severe performance of the faults in the area, which have a significant role in the geometry and distribution of the mineral masses.
The Dardvey fault with an NW-SE strike is one of the most important structural features in the Dardvey mining area. This fault plays a significant role in the distribution of mineral deposits in the Sangan area so that according to the structural evaluations, the movement of this fault has affected most faults of the area. Most faults of the area are strike-slip. The left-lateral strike-slip faults, with N, NW-S, SE strikes, can be introduced as Riedel fractures of this fault. On the other hand, right-lateral strike-slip faults, mostly having $\mathrm{E}-\mathrm{W}$ strikes, can be regarded as Antireidels of the fault. The normal faults have mainly a NE-SW strike and are distributed in the mining area.

In this study, the geostatistical analyses were employed to investigate the spatial distribution of the fault density in the deposit, and the results were presented as variograms and geostatistical contour maps for the faults and fractures. Based on the geostatistical analyses of the Sangan Dardvey deposit, the radius of influence of the faults was estimated at $25 \mathrm{~m}$.

According to the model proposed by Davis and Renolds [20], the structural model and pattern of the Dardvey deposit can be explained as the following: In this model, the Dardvey left-slip fault was considered the primary surface, while the left-lateral strike-slip faults in the N, NW-S, SE directions were considered the Riedels $(R)$ of this surface, and the right-lateral strike-slip ones in an E-W strike were regarded as Antiriedels ( $\left.R^{\prime}\right)$ of the surface. The model was built based on the directions of the stress field around the Dardvey fault with the maximum and minimum stress directions of NW-SE and NE-SW, respectively.

The structural studies showed that in the Sangan Dardvey deposits, the fractures play a crucial role in the fault zones, to which the existing anomalies are directly related.

The conducted investigations indicated that the tectonic structures mainly control the iron mineralization in the Dardvey deposits. Moreover, the extensional and compressional activities have played a dominant role in the formation processes of the Sangan mineral deposit.

In the Sangan area, the faults with a NE-SW trend and their movement, as well as renewed activity of the older (E-W) faults, have created fracture systems to form the deposit, and mineralization has occurred. These activities have continued and consequently resulted in the mineralization. In the next steps, the action of the younger faults has allowed for the displacement of the deposits. Two sets of faults with E-W and NE-SW strikes have facilitated the formation of the deposit. The $\mathrm{E}-\mathrm{W}$ fractures are old and associated with the basement faults, while the newer faults are related to the shear zones caused by the Dardvey strike-slip fault. By increasing the regional compressional stress in the shear zones, most of the hydrothermal solution moves laterally along the major fault, and the best places to trap the solution are the intersection 
points of the major fault with the auxiliary ones. Therefore, the movements of the Dorouneh fault (older right-slip and younger left-slip movements) have a considerable effect on the deposits of the Sangan mining area over different periods.

According to the mentioned information, the fault zones existing in the study area have a NE-SW strike and a high dip angle $\left(70^{\circ}-80^{\circ}\right)$ under the surface.

Acknowledgements This project was supported by the Islamic Azad University of Ferdows Branch Division Grant. The authors would like to express their appreciation to the authorities of the Iranian Mines \& Mining Industries Development \& Renovation (IMIDRO), who provided the facilities of mutual relations between Sangan Iron Ore Mine and the Islamic Azad University of Ferdows Branch.

\section{Compliance with ethical standards}

Conflict of interest The authors declare no conflict of interest.

\section{References}

1. Afzal P, Madani N, Shahbeik Sh, Yasrebi AB (2015) Multi-Gaussian kriging: a practice to enhance the delineation of mineralized zones by Concentration-Volume fractal model in Dardevey iron ore deposit, SE Iran. J Geochem Explor 158:10-21. https://doi. org/10.1016/j.gexplo.2015.06.011

2. Ahmadfaraj M, Mirmohammadi M, Afzal P, Yasrebi AB, Carranza EJ (2019) Fractal modeling and fry analysis of the relationship between structures and Cu mineralization in the Saveh region, Central Iran. Ore Geol Rev 107:172-185. https://doi. org/10.1016/j.oregeorev.2019.01.026

3. Alavi Naini M (1982) Geological quadrangle map of Khaf: series sheet 8059 , ministry of mines and metals. Geological Survey of Iran, Tehran

4. Bebbington $A$, Williams $M$ (2008) Water and mining conflicts in Peru. Mt Res Dev 28(3):190-195

5. Brems D, Muchez P, Sikazwe O, Mukumba W (2009) Metallogenesis of the Nkana copper-cobalt South orebody, Zambia. J Afr Earth Scl 55:185-196. https://doi.org/10.1016/j.jafrearsci .2009.04.003

6. Davis GH, Reynolds SJ, Kluth C (1996) Structural geology of rocks and regions

7. Feng X, Jessell MW, Amponsah PO, Martin R, Ganne J, Liu D, Batt GE (2016) Effect of strain-weakening on Oligocene-Miocene self-organization of the Australian-Pacific plate boundary fault in southern New Zealand: insight from numerical modeling. J Geodyn 100:130-143

8. Feng $X$, Zhang Q (2018) The effect of backfilling materials on the deformation of coal and rock strata containing multiple goaf: a numerical study. Minerals 8(6):224

9. Feng X, Zhang Q, Wang E, Ali M, Dong Z, Zhang G (2020) 3D modeling of the influenece of a splay fault on controlling the propagation of nonlinear stress waves induced by blast loading. Soil Dyn Earthq Eng. https://doi.org/10.1016/j.soild yn.2020.106335

10. Feng X, Zhang Q, Ali M (2020) Numerical Simulation of the Morphological effect of rock joints in the processes of concentrating Elatic Strain Energy: a direct shear study. Arab J Geosci. https:// doi.org/10.1007/s12517-020-5280-5
11. Feng X, Zhang Q, Ali M (2020) 3D modeling of the stringth effect of backfill-rocks on controlling rockbrust rick: a case study. Arab J Geosci 13(3):128

12. Golmohammadi A, Karimpour MH, Malekzadeh Shafaroudi A, Mazaheri SA (2015) Alteration-mineralization, and radiometric ages of the source pluton at the Sangan iron skarn deposit, northeastern Iran. Ore Geol Rev 65:545-563. https:// doi.org/10.1016/j.oregeorev.2014.07.005

13. Gongwen W, Yuan F, Emmanuel J, Carranza M, Ruixi L, Zonglie L, Zhankui F, Xiandong Z, Daojun W, Liang K, Wenjuan J, Botao W (2016) Hypomorphic characteristics of pyrite: criteria for 3D exploration targeting in the xishan gold deposit, China. J Geochem Explor 164:136-163. https://doi.org/10.1016/j.gexpl 0.2016 .01 .003

14. Grunewald U (2001) Water resources management in river catchments influenced by lignite mining. Ecol Eng 17(2-3):143-152

15. Härdle W, Tsybakov A (1997) Local polynomial estimators of the volatility function in nonparametric autoregression. J Econom 81:223-242. https://doi.org/10.1016/S0304-4076(97)00044-4

16. Hardcastle KC, Emery JM, Tinkham DJ, Brooks JA (1997) Photolineament factor analysis: a new computerized method of remotely assessing the degree to which bedrock is fractured. In: NWWA Conf. Innov. Ground Water Tech. of the 90's

17. Huang P, Yang P, Yizhou C, Liu C (2011) Three dimensional models of Cangshang gold mine based on Surpac. Int J Adv Comput Technol 3:299-306

18. Hustrulid W, Kuchta M, Martin R (2013) Open-pit mine planning and design, two-volume set \& CD-ROM pack. CRC Press, Boca Raton

19. Kim JG, Deo MD (2000) Finite element, discrete-fracture model for mulriphase flow in porous media. AIChE J 46(6):1120-1130

20. Liu L, Li J, Zhou R, Sun T (2016) 3D modeling of the porphyryrelated Dawangding gold deposit in south China: implications for ore genesis and resource evaluation. J Geochem Explor 164:164-185. https://doi.org/10.1016/j.gexplo.2015.11.002

21. Lkarmoty M, Colla C, Gabrielli E, Kasmaeeyazdi S, Tinti F, Bonduà $S$, Bruno R (2017) Mapping and modeling fractures using ground-penetrating radar for ornamental stone assessment and recovery optimization: two case studies. Min Geol Oil Proc 32:63-76. https://doi.org/10.17794/rgn\%20zbornik.v32i4.5110

22. Malekzadeh Shafaroudi A, Karimpour $\mathrm{MH}$, Golmohammadi A (2013) Zircon U-Pb geochronology and petrology of intrusive rocks in the C-North and Baghak districts, Sangan iron mine, NE Iran. J Asian Earth Sci 64:256-271. https://doi.org/10.1016/j. jseaes.2012.12.028

23. Mazaheri A (1995) Petrological studies of skarns from Marulan South, New South Wales, Australia and Sangan, Khorassan, Iran. Univ of Wollongong, Ph.D. thesis

24. Mazhari N, Malekzadeh Shafaroudi A, Ghaderi M, Star Lackey J, Lang Farmer G, Karimpour MH (2017) Geochronological and geochemical characteristics of fractionated I-type granites associated with the skarn mineralization in the Sangan mining region, NE Iran

25. Mazhari N, Malekzadeh Shafaroudi A, Ghaderi M (2015) Geology, mineralogy, and geochemistry of Ferezneh ferromanganese anomaly, east of Sangan mines complex, NE Iran. J Econ Geol $7: 3-4$

26. Mudd GM (2008) Sustainability reporting and water resources: a preliminary assessment of embodied water and sustainable mining. Mine Water Environ 27(3):136

27. Pandit B, Tiwari G, Latha GM (2018) Stability analysis of a large gold mine open-pit slope using advanced probalilistic method. Rock Mech Rock Eng 51(7):2153-2174

28. Patrick MB, Keller CP (1996) Multivariate interpolation to incorporate thematic surface data using inverse distance 
weighting (IDW). Comput Geosci 22:795-799. https://doi. org/10.1016/0098-3004(96)00021-0

29. Rezaei A, Hassani H, Moarefvand P, Golmohammadi A (2019) Determination of unstable tectonic zones in C-North deposit, Sangan, NE Iran using GPR method: importance of structural geology. J Min Environ (JME) 10:177-195. https://doi. org/10.22044/JME.2019.7378.1590

30. Sepidbar F, Mirnejad H, WeiLi J, Wei C, Luke LG, Kingsley B (2017) Mineral geochemistry of the Sangan skarn deposit, NE Iran: implication for the evolution of hydrothermal fluid. Geochemistry 77:399-419. https://doi.org/10.1016/j.chemer.2017.07.008

31. Sepibar F, Mirnejad H, Ma C (2018) Mineral chemistry and Ti in zircon thermometry: insights into magmatic evolution of the Sangan igneous rocks, NE Iran. Geochemistry 78:205-214. https ://doi.org/10.1016/j.chemer.2018.02.001

32. Shahbeik Sh, Afzal P, Moarefvand P, Qumarsy M (2014) Comparison between Ordinary Kriging (OK) and Inverse Distance Weighted (IDW) based on estimation error Case study: in Dardevey iron ore deposit, NE Iran. Arab J Geosci 7:3693-3704. https ://doi.org/10.1007/s12517-013-0978-2

33. Torremans K, Gauquie J, Boyce AJ, Barrie CD, Dewaele S, Sikazwe S, Muchez P (2013) Remobilisation features and structural control on ore grade distribution at the Konkola stratiform $\mathrm{Cu}-$ Co ore deposit, Zambia. J Afr Earth Sci 79:10-23. https://doi. org/10.1016/j.jafrearsci.2012.10.005

34. Vollgger SA, Cruden AR, Ailleres L, Cowan EJ (2015) Regional dome evolution and its control on ore-grade distribution: insights from 3D implicit modeling of the Navachab gold deposit, Namibia. Ore Geol Rev 69:268-284. https://doi. org/10.1016/j.oregeorev.2015.02.020

35. Yiping W, Cong C, Gaofeng H, Zhang Q (2014) Landslide stability analysis based on random fuzzy reliability: taking Liangshuijing landslide as a case. J Stoch Environ Res Risk Assess 28:17231732. https://doi.org/10.1007/s00477-013-0831-x

36. Zhang Q, Wang E, Feng X (2020) Rockbrust risk analysis during high-hard roof breaking in deep mines. Nat Resour Res. https:// doi.org/10.1007/s11053-020-09664-w

Publisher's Note Springer Nature remains neutral with regard to jurisdictional claims in published maps and institutional affiliations. 